7

\title{
An Efficient and Cost-effective Purification Methodology for SaCas9 Nuclease
}

Allen C. T. Teng ${ }^{1,2, *}$, Marjan Tavassoli ${ }^{1,2}$, Suja Shrestha ${ }^{1,3}$, Kyle Lindsay $^{2,4}$, Evgueni Ivakine ${ }^{2,4}$, Ronald $\mathrm{Cohn}^{4}$, J. Paul Santerre ${ }^{1,3}$, Anthony O. Gramolini ${ }^{1,2,}$

${ }^{1}$ Translational Biology and Engineering Program, Ted Rogers Centre for Heart Research, University of Toronto, Toronto, ON.

${ }^{2}$ Department of Physiology, Faculty of Medicine, University of Toronto, Toronto, ON.

${ }^{3}$ Faculty of Dentistry, University of Toronto, Toronto, ON

${ }^{4}$ Program in Genetics and Genome Biology, Hospital for Sick Children, Toronto, ON., Canada

Corresponding authors

\section{Abstract}

With an ever-increasing demand for laboratory-grade Cas9 proteins by many groups advancing the use of CRISPR technology, a more efficient and scalable process for generating the proteins, coupled with rapid purification methods is in urgent demand. Here, we introduce a modified methodology for rapid purification of active SaCas9 protein within 24 hours. The product has over $90 \%$ protein purity. The simplicity and cost-effectiveness of such methodology will enable general labs to produce a sizable amount of Cas9 proteins, further accelerating the advancement of CRISPR/Cas9-based research.

Key words Cas9, protein purification, IMAC, ion exchange chromatography.

\section{Corresponding authors}

Anthony O. Gramolini, PhD

Translational Biology and Engineering

Program

Ted Rogers Centre for Heart Failure

Department of Physiology, Faculty of

Medicine

University of Toronto

661 University Avenue, 14th Floor

Toronto, Ontario, M5G 1M1, Canada

Tel: 416-946-8257
38 Allen C. T. Teng, PhD

39 Translational Biology and Engineering

40 Program

41 Ted Rogers Centre for Heart Failure

42 Department of Physiology, Faculty of

43 Medicine

44 University of Toronto

45661 University Avenue, 14th Floor

46 Toronto, Ontario, M5G 1M1, Canada

47 Tel: 647-575-2301

48 Email: Allen.teng@utoronto.ca 


\section{Abbreviations}

51 CRISPR: Clustered Regularly Interspaced Short Palindromic Repeats

52 SaCas9: Staphylococcus aureus Cas9

53 CIEX: cation exchange chromatography

54 SDS-PAGE: sodium dodecyl sulphate-polyacrylamide gel electrophoresis

55 TCE: 2, 2, 2-trichloroethanol

56 FPLC: fast protein liquid chromatography

$57 \mathrm{ddH}_{2} \mathrm{O}$ : double distilled water

58 IPTG: Isopropyl-b-D-thiogalactopyranoside

59 dsDNA: Double-stranded DNA

60

61 


\section{Introduction}

63 Precise editing of genomic DNA remained challenging until the advent of the clustered regularly

64 interspaced short palindromic repeats (CRISPR)-associated protein (Cas) system. CRISPR/Cas

65 was first identified as an adaptive immune system in bacteria and archaea as a defense against

66 invading viruses and plasmids ${ }^{1}$. Different types of Cas proteins can target double stranded

67 DNA, single stranded DNA, or RNA ${ }^{2-6}$. One best characterized Cas subtype is Cas9, which has

68 now been routinely used for modifying genomic DNA of model organisms in laboratories. Of the

69 many identified Cas9 proteins, Cas9 from Staphylococcus aureus (SaCas9) has emerged as a

70 preferred genetic editing tool, because of its smaller size (1053 amino acids) allowing for an

71 efficient encapsulation into transfecting complexes or transducing viral DNA ${ }^{7,8}$. For example,

72 SaCas9 has been extensively used as a genome editing tool for developing an array of

73 therapeutic strategies investigating human inherited diseases in animal models ${ }^{2,9}$. However,

74 with an increasing demand, but currently time consuming and high cost-associated methods for

75 generating purified SaCas9, acquiring this protein remains a challenge for many laboratories

76 that are not adequately equipped for protein purification. Here, we report an advancement of

77 the purification methods for SaCas9 from bacterial cells. A major advantage of this

78 methodology is associated with achieving over $90 \%$ purity, at large batch sizes (concentrations

79 at $1 \mathrm{mg} / \mathrm{L}$ ) within a day. Purified SaCas9 can be directly used for in vitro applications. The new

80 methodology is superior to the majority of conventional approaches, which depends on French

81 press, high-frequency sonicator, or fast protein liquid chromatography ${ }^{10,11}$. 


\section{Materials and Methods}

\section{Materials}

85 A glycerol stock of XJb autolysis E. coli cells (ZYMO Research, Irvine, CA) containing the His ${ }_{8}^{-}$

86 TEV-SaCas9 (MN_548085.1) expression plasmid. LB broth, LB agar, carbenicillin, Isopropyl-b-

87 D-thiogalactopyranoside, L-arabinose, $\mathrm{MgCl}_{2}$, dithiothreitol, imidazole, PMSF are from Bioshop

88 (Toronto, Canada). HEPES, $\mathrm{KCl}, \mathrm{NaCl}$, glycerol, $\mathrm{MgCl}_{2}, 2,2,2-$ Trichloroethanol, and Amicon

89 Ultra-15 centrifugal filter units are from Sigma-Aldrich. Universal Nuclease (Pierce). HisTrap

90 high performance and HiTrap SP HP columns are from Cytiva.

\section{Methods}

\section{Overexpression of $\mathrm{His}_{8}$-TEV-SaCas9 proteins in E. coli.}

$94 \mathrm{XJb}$ E. coli cells (ZYMO research, Irvine, CA) containing His8-TEV-SaCas9 expression

95 plasmids were grown in a 4 L LB broth (Bioshop, Toronto, Canada) containing $100 \mu \mathrm{g} / \mathrm{mL}$ carbenicillin (Bioshop, Toronto, Canada) at $37^{\circ} \mathrm{C} / 250 \mathrm{rpm}$ until optical density $600 \mathrm{~nm}$ (O.D.600)

97 reached $0.6 \sim 0.8$ at $37^{\circ} \mathrm{C}$. Induced protein expression with $0.5 \mathrm{mM}$ IPTG (final concentration) and $3 \mathrm{mM} \mathrm{L-arabinose} \mathrm{solution} \mathrm{(final} \mathrm{concentration)} \mathrm{overnight} \mathrm{at} 180 \mathrm{rpm}, 18^{\circ} \mathrm{C}$. Next morning, bacteria pellet was collected by centrifugation at $6,000 \times g$ and suspended $1 \mathrm{~L}$ of bacteria pellet with $40 \mathrm{~mL}$ buffer A supplemented with $1 \mathrm{mM}$ PMSF. Homogenized bacteria can be stored at $80^{\circ} \mathrm{C}$ until protein purification.

104 Cells were lyzed in a $37^{\circ} \mathrm{C}$ water bath for 20 minutes and ribonucleic acids were digested with

$1050.75 \mu \mathrm{L}$ of universal ribonuclease (Pierce, 88701 ) at $37^{\circ} \mathrm{C}$ for 1 hour. Insoluble fraction was

106 removed by spinning protein lysate at $15,000 \mathrm{xg}$ for an hour and then soluble proteins were 107 filtered through a $0.22 \mu \mathrm{m}$ filter. $\mathrm{Ni}^{2+}-\mathrm{NTA}$ column connected to a syringe pump was set up as 108 shown in Figure 1. Equilibrated column with $25 \mathrm{~mL} d \mathrm{dH}_{2} \mathrm{O}, 25 \mathrm{~mL}$ solution $\mathrm{B}(20 \mathrm{mM} \mathrm{HEPES}$; 
pH 7.5, $300 \mathrm{mM} \mathrm{NaCl}, 250 \mathrm{mM}$ Imidazole, $0.5 \mathrm{mM}$ DTT), and $25 \mathrm{~mL}$ solution A (20 mM HEPES, $\mathrm{pH} 7.5,300 \mathrm{mM} \mathrm{NaCl}, 25 \mathrm{mM}$ Imidazole) at the rate of $4 \mathrm{~mL} / \mathrm{min}$. Applied filtered supernatant

111 into the $\mathrm{Ni}^{2+}-\mathrm{NTA}$ column at the rate of $2 \mathrm{~mL} / \mathrm{min}$. Washed column with $30 \mathrm{~mL}$ washing buffer

112 (21 mL solution $A+9 \mathrm{~mL}$ solution $\mathrm{B}, 30 \%$ solution $\mathrm{B})$. Eluted His ${ }_{8}$-TEV-SaCas9 proteins in 15

$113 \mathrm{~mL}$ elution buffer (100\% solution B). Ran $40 \mu \mathrm{L}$ eluted proteins on a SDS-PAGE gel for protein 114 visualization.

116 Cation exchange chromatography purification of $\mathrm{His}_{8}-\mathrm{SaCas} 9$ proteins.

117 Diluted eluted His ${ }_{8}$-TEV-SaCas9 proteins by 3-fold with $30 \mathrm{~mL}$ buffer $\mathrm{C}$ (20 mM HEPES; pH 7.5, $118200 \mathrm{mM} \mathrm{KCl}, 10 \mathrm{mM} \mathrm{MgCl}_{2}, 0.5 \mathrm{mM} \mathrm{DTT}$ ) and filter through a $0.22 \mu \mathrm{m}$ syringe filter. Set up 119 HiTrap SP HP column as shown in Figure 1A. Equilibrated column with $25 \mathrm{~mL} \mathrm{ddH}_{2} \mathrm{O}, 25 \mathrm{~mL}$ 120 solution D (20 mM HEPES; $\left.\mathrm{pH} 7.5,1 \mathrm{M} \mathrm{KCl}, 10 \mathrm{mM} \mathrm{MgCl}_{2}, 0.5 \mathrm{mM} \mathrm{DTT}\right)$, and $50 \mathrm{~mL}$ solution C 121 at the rate of $4 \mathrm{~mL} / \mathrm{min}$ sequentially. Applied filtered sample to the HisTrap column at the rate of $1222 \mathrm{~mL} / \mathrm{min}$. Washed column with $30 \mathrm{~mL}$ washing buffer $(24 \mathrm{~mL}$ solution $\mathrm{C}+6 \mathrm{~mL}$ solution $\mathrm{D}, 20 \%$ 123 solution D). Eluted $\mathrm{His}_{8}$-TEV-SaCas9 proteins in $20 \mathrm{~mL}$ elution buffer $(14 \mathrm{~mL}$ buffer $\mathrm{C}+6 \mathrm{~mL}$ 124 buffer D, 30\% solution D). Ran $40 \mu \mathrm{L}$ eluted proteins on a SDS-PAGE gel for protein 125 visualization.

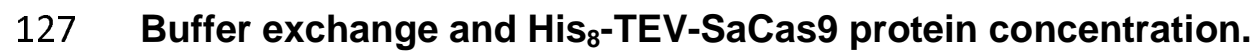

128 Concentrated eluted His8-TEV-SaCas9 proteins via a centrifugal filter unit (100 kDa cutoff, 129 Millipore) at $1,000 \mathrm{xg}$ for 5 minutes. Performed buffer exchange with $1 \mathrm{~mL}$ SaCas9 storage 130 buffer (10 mM Tris-HCl; pH 7.4, 300 mM NaCl, 0.1 mM EDTA, 1 mM DTT, and 50\% Glycerol) in 131 the centrifugal filter. Repeat this process 5 times. Transferred SaCas9 proteins into a $1 \mathrm{~mL}$ 132 Eppendorf tube and determine protein concentration via Bradford assays. Ran $40 \mu \mathrm{L}$ eluted 133 proteins on a SDS-PAGE gel for protein visualization. 


\section{Determine SaCas9 enzymatic activity.}

136 gRNA and template DNA are prepared as the following. Double stranded DNA (dsDNA) 137 encoding for a sgRNA targeting intron 55 (in55) of the mouse Dmd gene (ATG AAA CCA TGG 138 CAA GTA AG) was cloned using Bsal directional cloning into pX601 vector. Briefly, pX601 was 139 digested with Bsal and dephosphorylated with shrimp alkaline phosphatase (New England 140 Biolabs, M0371L). dsDNA in55 guide oligos were designed with 5'overhangs complimentary to

141 the sticky ends produced by Bsal digestion, phosphorylated with T4 polynucleotide kinase (New

142 England Biolabs, M0201L) and ligated into digested pX601. Accurate cloning of the guide was 143 confirmed by Sanger sequencing. In55 guide encoding DNA was amplified from the cloned 144 pX601-in55 vector with Q5 high-fidelity polymerase (New England Biolabs, M0494L), using 145 primers which introduced the minimal T7 promoter sequence upstream of the guide sequence 146 (Fwd: TAA TAC GAC TCA CTA TAG GGA TGA AAC CAT GGC AAG TAA G; Rvs: AAA ATC 147 TCG CCA ACA AGT TG). The amplicon was purified using the QIAquick PCR purification kit 148 (Qiagen, 28104), and sgRNA was in vitro transcribed from the amplicon using the 149 MEGAshortscript T7 transcription kit (Thermo Fisher Scientific, AM1354). The sgRNA was 150 purified with the RNEasy Mini Kit (Qiagen, 74104) following the manufacturer's protocol for RNA 151 cleanup.

152 SaCas9 was diluted to the final concentration of $500 \mathrm{ng} / \mu \mathrm{L}$ in SaCas9 working buffer (20 $153 \mathrm{mM}$ HEPES, $\mathrm{pH}$ 7.4, $150 \mathrm{mM} \mathrm{KCl}, 10 \%$ glycerol, $1 \mathrm{mM} \mathrm{DTT),} 300 \mathrm{ng} / \mu \mathrm{L}$ gRNA in 154 DNase/RNase-free water, and $60 \mathrm{ng} / \mu \mathrm{L}$ template DNA in DNase/RNase-free water. Mixed 155 together all components as depicted in Table 2, vortex, spin down, and incubate at $37^{\circ} \mathrm{C}$ water 156 bath for 1 hour. Inactivate SaCas 9 enzyme at $65^{\circ} \mathrm{C}$ for 10 minutes. Assessed digestion results 157 on a $1 \%$ agarose gel. 


\section{Results}

160 Protein purification is completed by a semi-automated system (Figure 1A) and consists of 3

161 simple steps - (1) an enrichment of His-tagged SaCas9 proteins via a Ni ${ }^{2+}-\mathrm{NTA}_{\text {column, }}(2)$ an

162 intermediate purification via a cation exchange chromatography (CIEX), and (3) and a final

163 buffer exchange via a centrifugal filtration (Figure 1B). For the chromatography setup, a 50-mL

164 syringe containing buffer or protein samples is mounted on a syringe pump, which controls the

165 solution flow rate applied to prepacked columns (Figure 1A). Eluted protein fractions are

166 monitored by sodium dodecyl sulphate-polyacrylamide gel electrophoresis (SDS-PAGE) with 2,

167 2, 2-trichloroethanol (TCE) staining. Fractions containing enriched SaCas9 proteins are

168 combined for subsequent fractionations.

169 Protein purification from bacterial lysates begins with cell lysis ${ }^{12-14}$. This initial isolation

170 step is commonly achieved using mechanical ${ }^{3,4}$ or chemical methods ${ }^{15}$, each with their own

171 limitations. For example, mechanical disruption is efficient in lysing cells, but devices such as a

172 French press or high-frequency sonicator may not be readily available to all laboratories.

173 Chemical lysis of cell walls has a tendency to denature target proteins ${ }^{16,17}$, further complicating

174 the downstream purification. To overcome these issues, XJb autolysis E. coli cells that express

$175 \lambda$ phage-endolysin for disrupting cell walls were selected as host cells for protein expression.

176 Lysis of E. coli containing SaCas9 proteins was achieved by a single freeze-and-thaw process.

177 Successful lysis was accompanied with an increased solution viscosity, which was reduced by a

178 ribonuclease treatment. Next, soluble protein lysate is prepared by centrifugation and degassed

179 by filtration before protein chromatography.

$180 \mathrm{Ni}^{2+}-\mathrm{NTA}$ chromatography is performed to enrich His ${ }_{8}-\mathrm{SaCas9}$. Analyses of SDS-PAGE

181 gels reveals that the majority of $\mathrm{His}_{8}$-SaCas9 proteins were eluted in a stepwise fashion

182 between 40\% (125 mM) and 100\% (275 mM) imidazole solution (Figure 2A, asterisk, SaCas9).

183 These fractions are combined and subjected to CIEX chromatography. Figure 2B shows that

184 SaCas9 proteins are further fractionated by CIEX chromatography. Specifically, most SaCas9 
185 proteins are eluted stepwise in the presence of 30-40\% (500-600 mM KCl) solution D. Keeping

$186 \mathrm{~K}^{+}$ion concentrations below $600 \mathrm{mM}$ reduces protein contaminants. Finally, protein

187 concentration and buffer exchange are completed in a centrifugal filtration unit. Figure 2C

188 shows that sequentially purified SaCas9 proteins have an average purity of $>90 \%$, based on

189 multiple rounds of protein fractionation. The protein yield from this protocol ranges between 1

$190 \mathrm{mg}$ per liter of bacterial culture. The estimated cost for $10 \mathrm{mg}$ of purified Cas 9 proteins is 86.36

\section{USD (Table 1).}

192 Next, we sought to benchmark the purity, production cost, and enzymatic activity of our

193 SaCas9 by comparing it to commercially available sources. Figure 3A shows that the purity of

194 this protein is comparable to two commercial suppliers. The production cost associated with this

195 protocol is the lowest - 86.36 USD per $10 \mathrm{mg}$ of proteins (Table 1). For determining an activity

196 of purified SaCas9 nucleases, enzymes were mixed with template DNA and gRNA. Digested

197 DNA was visualized on a 1\% agarose gel. Figure 3B shows that template DNA was completely

198 digested by the de novo generated SaCas9 (Figure 3B, lane 4) and is comparable to 199 commercially supplied enzymes (Figure 3B, lane 3). Together, our results show that purified 200 SaCas9 remains fully active for downstream applications. 


\section{Discussion}

203 In this study, we have demonstrated a modified procedure for purifying SaCas9 from bacterial

204 lysates. The advantages of this method include simplicity and cost-effectiveness. The procedure

205 can be completed within a day by trained personnel and requires only common lab equipment.

206 This process will enable the acceleration of CRISPR/Cas research by providing an easier

207 access to lower cost and highly pure SaCas9 proteins. In addition, different Cas proteins have

208 been purified via $\mathrm{Ni}^{2+}-\mathrm{NTA}$ and CIEX chromatography ${ }^{2-4}$, thus the reported method can facilitate

209 Cas protein research by further refining the elution buffer concentration for CIEX

210 chromatography. There are, however, two major disclosures associated with this method when

211 compared with fast protein liquid chromatography (FPLC)-based purification. First, the system

212 lacks real-time monitoring for protein elution from chromatography. In modern FPLC, optical

213 density at $280 \mathrm{~nm}$ wavelength (O.D.280) is usually used for keeping track of protein elution.

214 Although such an optical setup is not included in the reported method, SaCas9 can be directly

215 visualized in the TCE-stained SDS-PAGE gels within 30 minutes of chromatography ${ }^{18-20}$. The

216 second limitation is the absence of a pressure monitor for prepacked columns. Nevertheless,

217 changes of column pressure can be indirectly reflected by the reduced flow rate of solution

218 output. During chromatography, a $20 \%$ reduction in flow rate should serve as a sign of

219 increasing column pressure, and the need for an intervention step. Column cleaning and

220 maintenance should be performed as per manufacturer's manual after three rounds of

221 chromatography, in order to ensure maximal column performance. 
bioRxiv preprint doi: https://doi.org/10.1101/2021.06.08.447622; this version posted June 8, 2021. The copyright holder for this preprint (which was not certified by peer review) is the author/funder, who has granted bioRxiv a license to display the preprint in perpetuity. It is made available under aCC-BY-NC-ND 4.0 International license.

\section{Acknowledgement}

224 This study was supported by a Medicine by Design New Ideas Fund (MBDNI-201) and a 225 Jesse's Journey-The Foundation for Gene and Cell Therapy (\#507052), and the Translational 226 Biology and Engineering Program (University of Toronto) seed grant. 


\section{References}

2291 Jinek, M. et al. (2012). A programmable dual-RNA-guided DNA endonuclease in 230 adaptive bacterial immunity. Science 337, 816-821, doi:10.1126/science.1225829.

2312 Kemaladewi, D. U. et al. (2017). Correction of a splicing defect in a mouse model of 232 congenital muscular dystrophy type 1A using a homology-directed-repair-independent 233 mechanism. Nature medicine 23, 984-989, doi:10.1038/nm.4367.

2343 Abudayyeh, O. O. et al. (2017). RNA targeting with CRISPR-Cas13. Nature 550, 280235284 , doi:10.1038/nature24049.

2364 Harrington, L. B. et al. (2018). Programmed DNA destruction by miniature CRISPR237 Cas14 enzymes. Science 362, 839-842, doi:10.1126/science.aav4294.

2385 Garcia-Doval, C. et al. (2020). Activation and self-inactivation mechanisms of the cyclic 239 oligoadenylate-dependent CRISPR ribonuclease Csm6. Nature communications 11, 240 1596, doi:10.1038/s41467-020-15334-5.

2416 Swarts, D. C. \& Jinek, M. (2019). Mechanistic Insights into the cis- and trans-Acting 242 DNase Activities of Cas12a. Molecular cell 73, 589-600 e584, 243 doi:10.1016/j.molcel.2018.11.021.

2447 Lu, B. et al. (2019). Delivering SaCas9 mRNA by lentivirus-like bionanoparticles for 245 transient expression and efficient genome editing. Nucleic acids research 47, e44, 246 doi:10.1093/nar/gkz093.

2478 Xie, H. et al. (2020). High-fidelity SaCas9 identified by directional screening in human 248 cells. PLoS biology 18, e3000747, doi:10.1371/journal.pbio.3000747.

2499 Kemaladewi, D. U. et al. (2019). A mutation-independent approach for muscular 250 dystrophy via upregulation of a modifier gene. Nature 572, 125-130, 251 doi:10.1038/s41586-019-1430-x.

25210 Nishimasu, H. et al. (2015). Crystal Structure of Staphylococcus aureus Cas9. Cell 162, 253 1113-1126, doi:10.1016/j.cell.2015.08.007. 
25411 Rajagopalan, N., Kagale, S., Bhowmik, P. \& Song, H. (2018). A Two-Step Method for Obtaining Highly Pure Cas9 Nuclease for Genome Editing, Biophysical, and Structural Studies. Methods and protocols 1, doi:10.3390/mps1020017.

25712 Ma, J. et al. (2021). Nanoparticle-Mediated Assembly of Peptoid Nanosheets Functionalized with Solid-Binding Proteins: Designing Heterostructures for Hierarchy. Nano letters 21, 1636-1642, doi:10.1021/acs.nanolett.0c04285. proteins on silica-derivatized spin columns and 96-well plates. Protein expression and purification 170, 105608, doi:10.1016/j.pep.2020.105608. Phase Control of Nanocrystalline Inclusions in Bioprecipitated Titania with a Panel of Mutant Silica-Binding Proteins. Langmuir : the ACS journal of surfaces and colloids 36,

26715 Lu, Z. et al. (2020). Targeting Cancer Gene Dependencies with Anthrax-Mediated Delivery of Peptide Nucleic Acids. ACS chemical biology 15, 1358-1369,

27016 Hartrampf, N. et al. (2020). Synthesis of proteins by automated flow chemistry. Science 368, 980-987, doi:10.1126/science.abb2491.

27217 Vorobieva, A. A. et al. (2021). De novo design of transmembrane $\beta$ barrels. Science 371, doi:10.1126/science.abc8182.

27418 Ladner, C. L., Edwards, R. A., Schriemer, D. C. \& Turner, R. J. (2006). Identification of 275 trichloroethanol visualized proteins from two-dimensional polyacrylamide gels by mass spectrometry. Analytical chemistry 78, 2388-2396, doi:10.1021/ac051851y.

27719 Ladner, C. L., Yang, J., Turner, R. J. \& Edwards, R. A. (2004). Visible fluorescent detection of proteins in polyacrylamide gels without staining. Analytical biochemistry 326, 13-20, doi:10.1016/j.ab.2003.10.047. 
bioRxiv preprint doi: https://doi.org/10.1101/2021.06.08.447622; this version posted June 8, 2021. The copyright holder for this preprint (which was not certified by peer review) is the author/funder, who has granted bioRxiv a license to display the preprint in perpetuity. It is made available under aCC-BY-NC-ND 4.0 International license.

28020 Chopra, A., Willmore, W. G. \& Biggar, K. K. (2019). Protein quantification and visualization via ultraviolet-dependent labeling with 2,2,2-trichloroethanol. Scientific reports 9, 13923, doi:10.1038/s41598-019-50385-9. 


\section{Tables}

\section{Table 1}

\begin{tabular}{|c|c|}
\hline & unit price in USD \\
\hline HisTrap column (GE, 17524802) & 185.00 \\
\hline HiTrap column (GE, 17115401) & 82.40 \\
\hline Amicon Ultra Centrifugal Filter Unit (Sigma, UFC901024) & 332.50 \\
\hline LB broth (Bioshop Canada, LBL405) & 68.76 \\
\hline LJB autolysis cells (Zymo Research Corporation, 50-444-646) & 21.90 \\
\hline PES Bottle Top Filters (Fisher Scientifics, FB12566511) & 73.00 \\
\hline Miscellaneous (Salt, glass bottles, carbenicilline, arabinose, etc) & 100.00 \\
\hline Total cost for 100 mg of SaCas9 proteins & 863.56 \\
\hline Cost per 10 mg of SaCas9 proteins & 86.36 \\
\hline
\end{tabular}


bioRxiv preprint doi: https://doi.org/10.1101/2021.06.08.447622; this version posted June 8, 2021. The copyright holder for this preprint (which was not certified by peer review) is the author/funder, who has granted bioRxiv a license to display the preprint in perpetuity. It is made available under aCC-BY-NC-ND 4.0 International license.

\section{Table 2}

\begin{tabular}{|c|c|c|c|c|c|}
\hline & $\begin{array}{l}\text { SaCas9 } \\
(500 \mathrm{ng} / \mu \mathrm{l})\end{array}$ & $\begin{array}{l}\text { gRNA } \\
\text { (300 ng) }\end{array}$ & $\begin{array}{l}\text { Template } \\
\text { DNA (60 ng) }\end{array}$ & $\begin{array}{c}\text { 10X reaction } \\
\text { buffer }\end{array}$ & ddH2O \\
\hline $\begin{array}{c}\text { Template DNA } \\
\text { only }\end{array}$ & & & 1 & 2 & 17 \\
\hline gRNA only & & 1 & & 2 & 17 \\
\hline Mock digestion & & 1 & 1 & 2 & 16 \\
\hline Digestion & 1 & 1 & 1 & 2 & 15 \\
\hline
\end{tabular}




\section{Figure captions}

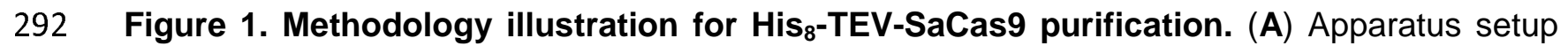

293 for protein purification. A 50-mL syringe (2) mounted on a syringe pump (1) is connected to a

294 pre-packed column (3). Loading of protein samples and buffer application can be swiftly 295 adapted by changing different syringes. Eluted samples can be collected in tubes (4). (B) The 296 summary of SaCas9 purification procedure introduced in this study. SaCas9 expression is 297 induced overnight in $\mathrm{XJb}$ cells. Protein purification is performed by $\mathrm{Ni}^{2+}-\mathrm{NTA}$ and CIEX 298 chromatography as illustrated in Fig. 1A. Final protein is concentrated and buffer exchanged in 299 a centrifugal filter unit. Confirmation of protein purity is monitored by TCE staining of SDS-PAGE 300 gels.

301

Figure 2. Analyses of Coomassie brilliant blue and TCE stained SDS-PAGE gels for

purified $\mathrm{His}_{8}$-SaCas9 proteins. (A) Affinity purification of $\mathrm{His}_{8}-\mathrm{SaCas} 9$. Soluble $\mathrm{His}_{8}$-SaCas9 from bacterial lysates were enriched in a $\mathrm{Ni}^{2+}$-NTA column and were eluted in increasing concentration (10-100\%) of solution B. Majority of impurity was washed off with $30 \%$ solution B and $\mathrm{His}_{8}$-SaCas9 proteins were eluted in $15 \mathrm{~mL}$ of $100 \%$ buffer $\mathrm{B}$. Top panel, CBB staining; Bottom panel, TCE staining. (B) Intermediate purification of $\mathrm{His}_{8}-\mathrm{SaCas} 9$ with $\mathrm{CIEX}$. His ${ }_{8}^{-}$ SaCas9 proteins from $\mathrm{Ni}^{2+}$-NTA-based affinity purification were further fractionated CIEX and proteins were eluted in increasing concentration (10-100\%) of buffer D in a stepwise fashion. Majority of SaCas9 proteins were eluted in 30 and $40 \%$ fractions and were combined and buffer

311 exchanged in centrifugal filter unit. Top panel, CBB staining; Bottom panel, TCE staining. (C) A

312 representative image of sequentially purified His8-SaCas9 proteins. Total proteins from cell-free

313 Iysate, $\mathrm{Ni}^{2+}-\mathrm{NTA}$ elution, and centrifugal filtration were visualized on a coomassie brilliant blue-

314 stained SDS-PAGE gel. Top panel, CBB staining; Bottom panel, TCE staining. CFL, cell-free 315 lysate; FT, flow through; *, His ${ }_{8}$-SaCas9. 
317 Figure 3. Comparison of homemade SaCas9 to commercial sources. (A) Homemade

318 SaCas9 purification procedure achieves $90 \%$ purity, which is comparable to commercial

319 suppliers. The purity of de novo SaCas9 proteins (1) was visualized side-by-side with 2 other

320 commercial sources (2 \& 3) on either CBB or TCE-stained SDS-PAGE gels. The average cost

321 of SaCas9 proteins purified according to the reported method is $8.64 \mathrm{USD} / \mathrm{mg}$. (B) Purified

322 SaCas9 efficiently digested double stranded DNA. SaCas9-mediated DNA digestion was

323 analyzed on a $1 \%$ agarose gel. A full-length (undigested) template DNA and gRNA were

324 detected in lanes 1 and 2, respectively. A complete digestion of template DNA with

325 commercially supplied SaCas9 was included as a positive control and showed 2 separate

326 fragments (2 and 1 kilobase pairs) in lane 3. A complete digestion of template DNA with

327 homemade SaCas9 was also observed as 2 fragments in lane 4. 
bioRxiv preprint doi: https://doi.org/10.1101/2021.06.08.447622; this version posted June 8, 2021. The copyright holder for this preprint (which was not certified by peer review) is the author/funder, who has granted bioRxiv a license to display the preprint in perpetuity. It is made available under aCC-BY-NC-ND 4.0 International license.

\section{$329 \quad$ Figures}

Figure 1

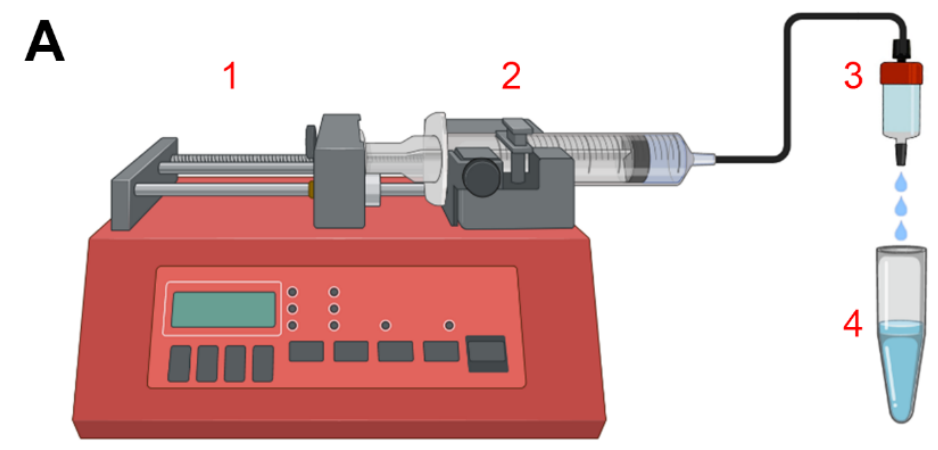

B

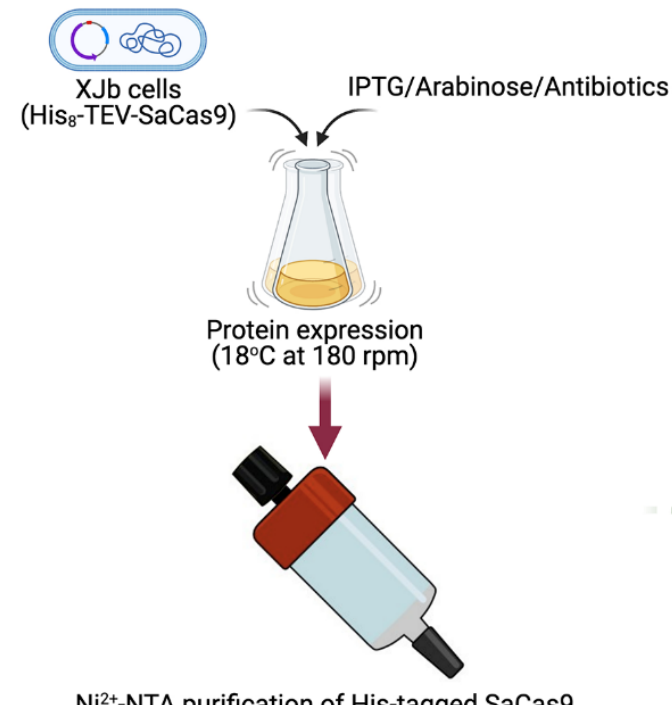

$\mathrm{Ni}^{2+}-\mathrm{NTA}$ purification of His-tagged SaCas 9

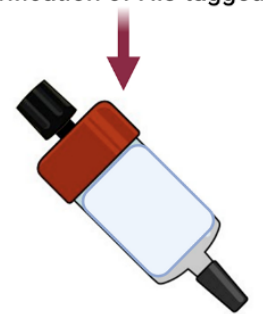

Cation exchange chromatography

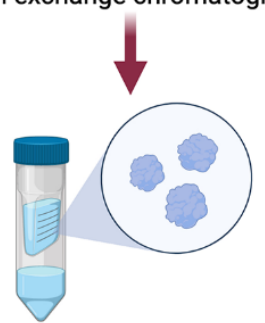

Centrifuge filter unit (buffer exchange and polishing)
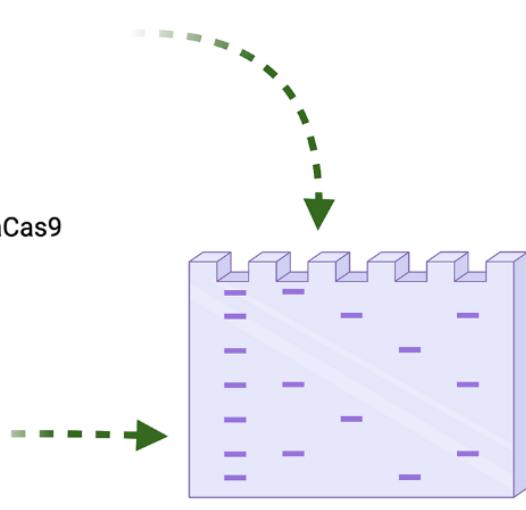

Confirmation of SaCas9

(SDS-PAGE/TCE staining)

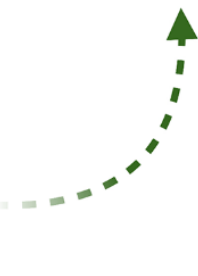




\section{Figure 2}
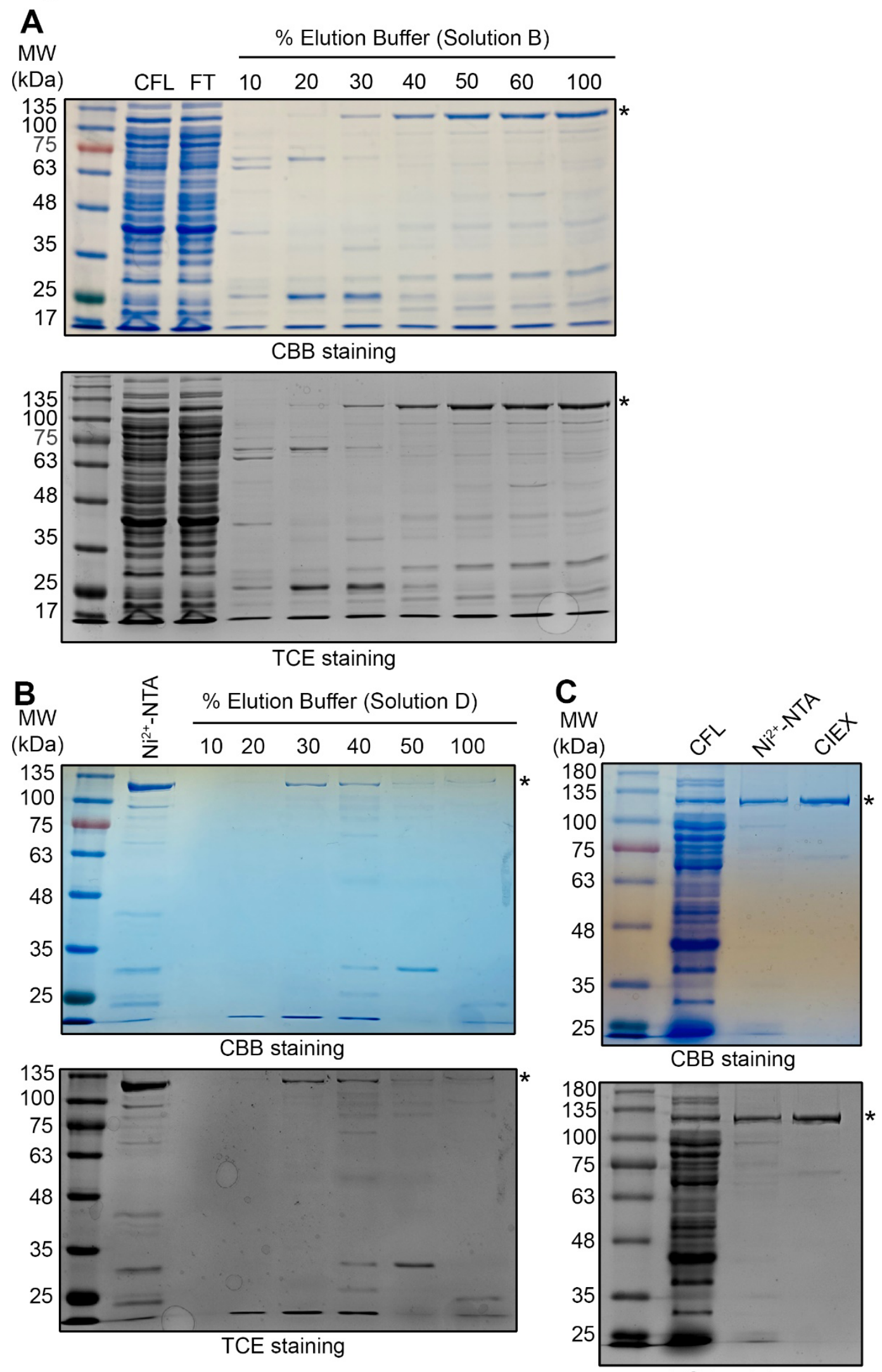

TCE staining

TCE staining 


\section{Figure 3}

A MW
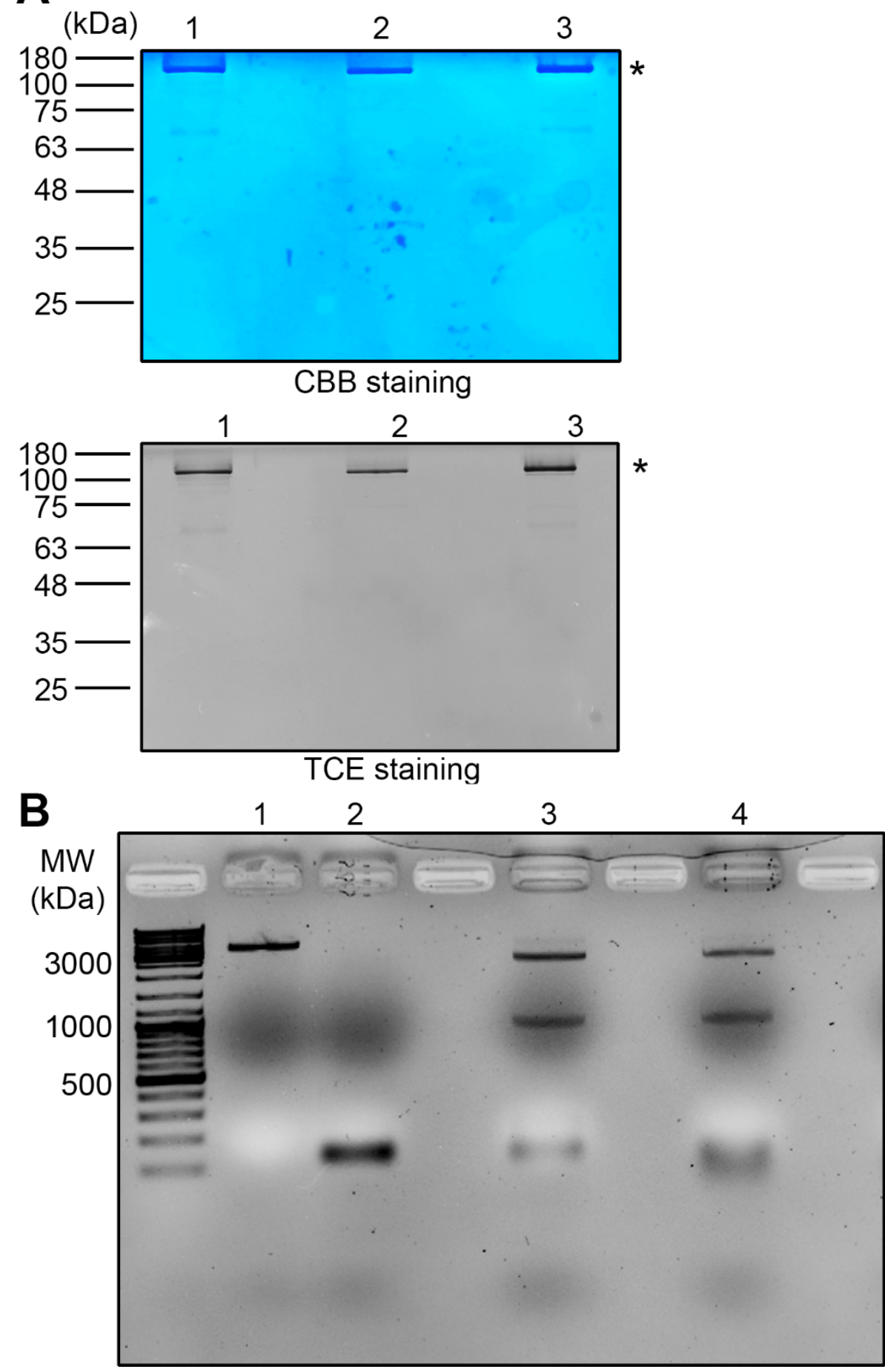